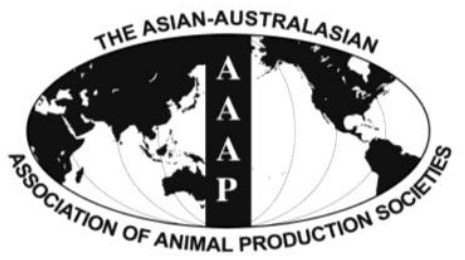

Asian Australas. J. Anim. Sci.

Vol. 26, No. 9 : 1282-1288 September 2013

http://dx.doi.org/10.5713/ajas.2012.12634

www.ajas.info

pISSN 1011-2367 elSSN 1976-5517

\title{
Net Phosphorus Requirements of DorperxThin-tailed Han Crossbred Ram Lambs
}

\author{
Shoukun Ji, Guishan Xu, Chenggang Jiang, Kaidong Deng ${ }^{1}$, Yan Tu, Naifeng Zhang, \\ Tao Ma, Can Lou, and Qiyu Diao* \\ Institute of Feed Science, Chinese Academy of Agricultural Sciences, Beijing 100081, China
}

\begin{abstract}
A comparative slaughter trial was conducted to estimate the phosphorus (P) requirement for maintenance and growth of crossbred lambs of Dorper with a Chinese indigenous sheep breed, thin-tailed Han sheep. Thirty-five Dorper $\times$ thin-tailed Han crossbred, noncastrated ram lambs $(20.3 \pm 0.22 \mathrm{~kg}$ of shrunk body weight (SBW)) were used. Seven lambs were randomly chosen and slaughtered at $20 \mathrm{~kg} \mathrm{SBW}$ as the baseline group for measuring initial body composition. Another seven lambs were also randomly chosen and offered a pelleted mixed diet for ad libitum intake and slaughtered at $28 \mathrm{~kg} \mathrm{SBW}$. The remaining 21 sheep were randomly divided into 3 groups with 7 sheep each and subject to the same diet of either 70 or $40 \%$ of ad libitum intake. The 3 groups were slaughtered when the sheep fed ad libitum reached $35 \mathrm{~kg}$ of SBW. Body P contents were determined after slaughter. The results showed that the net P requirement for maintenance was $30.0 \mathrm{mg} / \mathrm{kg}$ of empty body weight (EBW) or $23.4 \mathrm{mg} / \mathrm{kg}$ body weight $(\mathrm{BW})$, and the P requirement for growth decreased from 5.3 to $5.0 \mathrm{~g} / \mathrm{kg}$ of EBW gain as the lamb grew from 20 to $35 \mathrm{~kg}$. The net P requirement for growth of Dorper $\times$ thin-tailed Han crossbred ram lambs was lower than that of sheep adopted by the American nutritional system. (Key Words: P Requirement, Comparative Slaughter Trial, Maintenance, Growth, Lambs)
\end{abstract}

\section{INTRODUCTION}

Phosphorus $(\mathrm{P})$ is one of the essential elements that not only plays an important role in animal health, growth and production performance, but also represents the most potential risk of environmental pollution (Myers et al., 2009). Therefore, dietary P should be appropriate for optimum animal performance with minimum environmental impacts. The thin-tailed Han sheep is a Chinese indigenous breed that is well adapted to the ecological conditions of semi-arid agricultural areas of China and is noted for its precociousness and prolificacy (Cheng, 1984). The Dorper sheep, originated from South Africa and characterized by hardiness, early maturity and fast growth (Cloete et al., 2000), was imported into China as a meat sire breed to improve growth performance and carcass traits of the thintailed Han sheep. Although the Dorper $\times$ thin-tailed Han crossbreed has been widely raised in China in recent years,

\footnotetext{
* Corresponding Author: Q. Y. Diao. Tel: +86-10-8210-6055, ax: +86-10-6216-9105, E-mail: diaoqiyu@ mail.caas.net.cn

${ }^{1}$ College of Animal Science, Jinling Institute of Technology, Nanjing, Jiangsu 210038, China.

Submitted Nov. 11, 2012; Accepted Jan. 17, 2013; Revised May 26, 2013
}

the nutritional requirements of this sheep breed have not been well established. The British (AFRC, 1993), French (INRA, 1989), Australian (CSIRO, 2007), and American (NRC, 1985) nutritional systems are most commonly adopted for diet formulation worldwide, but the recommended allowances of $\mathrm{P}$ for sheep vary with the systems. Currently, the factorial method which predicts $P$ requirements under a wide range of production circumstances is commonly adopted for nutrition requirement studies, but estimates of $\mathrm{P}$ requirements from different authorities varies (AFRC, 1991). Moreover, multiple factors may contribute to the variation of $\mathrm{P}$ requirements of sheep such as breeds (McDowell, 1996), maturity and the corresponding changes in $\mathrm{P}$ deposition in the bone (NRC, 2007). As a result, using one model to apply to all cases may be not ideal, and an accurate assessment of the P requirement by the Dorper $\times$ thin-tailed Han sheep is therefore critical for fulfilling its performance potential and efficient feed utilization.

As a part of a national research program on nutritional requirements of Chinese sheep for meat production, this study was designed to determine the $\mathrm{P}$ requirement of crossbred lambs of Dorper $\times$ thin-tailed Han sheep using the 
comparative slaughter technique. The outcome would be expected to provide guidance for efficient feeding management of this crossbred sheep in China.

\section{MATERIALS AND METHODS}

This research was conducted from March to June 2011 at the Nankou Experimental Station of the Chinese Academy of Agricultural Sciences (CAAS), Beijing, China. During the research period, an enclosed facility equipped with heating radiators was used to keep the inside temperature stable with the maximum and minimum temperature recorded as 26.5 and $15.5^{\circ} \mathrm{C}$, respectively. The experimental protocol was approved by CAAS Animal Ethical Committee, and humane animal care and handling procedures were followed throughout the experiment.

\section{Comparative slaughter trial}

Animals, feedstuffs, housing, and experimental design: Thirty-five Dorper $\times$ thin-tailed Han crossbred ram lambs were weaned at around $45 \mathrm{~d}$ of age and offered the experimental diet (Table 1) for ad libitum consumption until the beginning of the trial $(20.3 \pm 0.22 \mathrm{~kg} \mathrm{SBW})$. After being drenched with $0.2 \mathrm{mg}$ ivermectin per $\mathrm{kg}$ of $\mathrm{BW}$ against endoparasites, all lambs were confined to individual stainless steel pens $\left(3.2 \times 0.8 \mathrm{~m}^{2}\right)$ equipped with feeders and automatic water suppliers.

Seven randomly selected lambs were slaughtered at 20 $\mathrm{kg}$ of SBW as the baseline group for measuring initial body composition. Another 7 randomly selected lambs were fed

Table 1. Ingredients and nutrient composition of the experimental diet (dry matter basis)

\begin{tabular}{|c|c|}
\hline Item & Proportion $(\%)$ \\
\hline \multicolumn{2}{|l|}{ Ingredients } \\
\hline Milled Chinese wildrye hay & 55.00 \\
\hline Cracked corn grain & 29.40 \\
\hline Soybean meal & 14.00 \\
\hline Dicalcium phosphate & 0.86 \\
\hline Salt & 0.50 \\
\hline Premix $^{a}$ & 0.24 \\
\hline \multicolumn{2}{|l|}{ Nutrient composition (analyzed) } \\
\hline $\mathrm{CP}$ & 12.45 \\
\hline $\mathrm{ME}^{\mathrm{b}}(\mathrm{MJ} / \mathrm{kg})$ & 9.30 \\
\hline Ether extract & 2.84 \\
\hline $\mathrm{NDF}$ & 45.49 \\
\hline $\mathrm{ADF}$ & 23.59 \\
\hline $\mathrm{Ca}^{\mathrm{c}}$ & 0.71 \\
\hline $\mathrm{P}$ & 0.33 \\
\hline \multicolumn{2}{|c|}{$\begin{array}{l}\text { a The premix provided the following nutrients per } \mathrm{kg} \text { of the diet: } 15,000 \\
\mathrm{IU} \mathrm{VA}, 5,000 \mathrm{IU} \mathrm{VD}, 50 \mathrm{mg} \mathrm{VE}, 32 \mathrm{~g} \mathrm{Na}, 92 \mathrm{~g} \mathrm{~K}, 23 \mathrm{~g} \mathrm{Mg}, 90 \mathrm{mg} \mathrm{Fe} \text {, } \\
12.5 \mathrm{mg} \mathrm{Cu}, 50 \mathrm{mg} \mathrm{Mn}, 100 \mathrm{mg} \mathrm{Zn}, 0.3 \mathrm{mg} \mathrm{Se}, 0.8 \mathrm{mg} \text { I, and } 0.5 \mathrm{mg} \mathrm{Co} \text {. } \\
\text { be }{ }^{\mathrm{b}} \text { Energy value estimated based on computation per NRC (2007). } \\
{ }^{\mathrm{c}} \text { Calcium value was measured based on AOAC (1990, method 927.02). }\end{array}$} \\
\hline
\end{tabular}

for ad libitum and slaughtered as an intermediate slaughter group when they reached $28 \mathrm{~kg}$ of SBW. On $\mathrm{d} 0$, the remaining 21 lambs were randomly assigned to 3 levels of dry matter intake (DMI): ad libitum, or restricted to either 70 or $40 \%$ of ad libitum intake, which were expected to achieve gains of 300, 200 and $0 \mathrm{~g} / \mathrm{d}$, respectively, according to NRC (2007). These lambs were pair-fed in 7 slaughter groups with each consisting of 1 lamb from each treatment. All 3 lambs from a slaughter group were fasted and slaughtered when the lamb fed ad libitum reached $35 \mathrm{~kg}$ of SBW.

The experimental diet was formulated as a pelleted mixed diet based on corn, soybean meal and hay with a concentrate:roughage ratio of 44:56 (DM basis) (Table 1). The choice of a pelleted diet was to prevent possible selectivity and waste and to facilitate accurate measurements of feed intake.

Animals were fed once daily at $0800 \mathrm{~h}$ and had free access to clean water. The amount of feed offered to the $\mathrm{ad}$ libitum group was adjusted daily in the morning to ensure a $10 \%$ refusal based on the DMI of the previous day. The amount of feed offered to restricted feed intake groups was also calculated daily, based on the DMI of the ad libitum group from the previous day. Individual samples of feed offered and orts (approximately 10\% of total) were taken daily and frozen $\left(-20^{\circ} \mathrm{C}\right)$. These samples were eventually pooled to an individual composite sample for each animal, oven-dried at $55^{\circ} \mathrm{C}$ for at least $72 \mathrm{~h}$, ground and stored until analyses.

Before slaughter, BW was measured at $1600 \mathrm{~h}$ a day before, then feed and water were withdrawn for $16 \mathrm{~h}$, and then SBW was measured. At slaughter, a container was adopted to collect the blood when exsanguination with conventional humane procedures was used to kill the lambs: the lambs were euthanized by inhalation of $\mathrm{CO}_{2}(99.99 \%$, Beijing AP BAIF Gases Industry Co., Ltd., Beijing, China) via a canine anesthesia mask connected to a gas cylinder equipped with a flow controller. After slaughter, the body was dissected, and weights of the blood, carcass, head, feet, hide, wool, viscera, and adipose tissues removed from the internal organs were recorded. The digestive tract (esophagus, rumen, reticulum, omasum, abomasum, and small and large intestines) content was removed before the digestive tract was flushed with tap water, the excess water was then stripped manually, and weighed again. The EBW was computed as the sum of individual components weights except the digestive tract content.

Carcasses and heads were split at dorsal midline as described by Galvani et al. (2008; 2009). The right-half carcass, as well as the right-half head and anterior and posterior right feet, was weighed separately and dissected into muscle, bone, and fat, and weighed individually; the bone was ground with a bone miller (Model SGJ-3600, 
Langfang Huiyong Machinery Plant, Hebei, China) through an $8-\mathrm{mm}$ screen, homogenized by 3 additional passes through the miller; the other separate body components were cut into small pieces, fully ground with an electrical screw grinder (Model 12, Shanghai Xinmai Machinery Plant, Shanghai, China) through a 4-mm screen, and homogenized. A $500 \mathrm{~g}$ sub-sample of each component was taken and stored at $-20^{\circ} \mathrm{C}$.

\section{Chemical analyses}

Feeds and orts samples: The DM contents of feeds and orts were analyzed by drying at $135^{\circ} \mathrm{C}$ for $2 \mathrm{~h}$ (AOAC, 1990; method 930.15). Crude ash was determined by complete combustion in a muffle furnace at $600^{\circ} \mathrm{C}$ for $4 \mathrm{~h}$, the $\mathrm{P}$ concentrations in feed and orts were measured by the colorimetric assay adapted from AOAC (1990; method 965.17): The remained ash was digested in $6 \mathrm{~mol} / \mathrm{L} \mathrm{HCl}$ first, then molybdovanadate reagent was added to react with $\mathrm{P}$ for color development for $15 \mathrm{~min}$. The $\mathrm{P}$ concentration was determined by using a spectrophotometer (Model 752, Hengping Scientific Instruments Co. Ltd., Shanghai, China). $\mathrm{P}$ was not detected in drinking water for the lambs, and the recovery rate of $\mathrm{P}$ in samples measured was $98.9 \%$.

Body components: A 100-g subsample from each initial sample with the exception of the wool was lyophilized for $72 \mathrm{~h}$ to determine DM content, and then all the subsamples including the wool were determined for crude ash and $\mathrm{P}$ as described above.

\section{Data calculations and analyses}

Prediction of the initial body $P$ content: Body $\mathrm{P}$ content was calculated as the sum of the content of all body components. Initial body $\mathrm{P}$ content of each animal from intermediate and final slaughter groups was calculated using a regression equation developed for the relationship between body P content and EBW of baseline animals.

Requirements for maintenance: Retained $\mathrm{P}$ was calculated as the difference between final and initial body $\mathrm{P}$ content of each animal from intermediate and final slaughter groups, and the total $\mathrm{P}$ losses were calculated as the difference between $\mathrm{P}$ intake and retained $\mathrm{P}$. A linear regression of daily $P$ retained $(\mathrm{g} / \mathrm{kg}$ of $\mathrm{EBW})$ on dry mater intake $(\mathrm{kg} / \mathrm{kg}$ of EBW) was developed to predict the net $\mathrm{P}$ requirement for maintenance by extrapolating the linear regression until DMI $=0$, and the intercept of this regression represented unavoidable $\mathrm{P}$ losses which represented the net $\mathrm{P}$ requirement for maintenance $(\mathrm{g} / \mathrm{kg}$ $\mathrm{EBW} \cdot \mathrm{d})$.

Requirements for growth: An allometric equation for the relationship between empty body $\mathrm{P}$ content $(\mathrm{g})$ and EBW (kg) was used to predicted the body P composition (ARC, 1980): $\log$ (body $\mathrm{P}$ content, $\mathrm{g})=\mathrm{a}+\mathrm{b} \times \log (\mathrm{EBW}, \mathrm{kg}$ ), this equation was then differentiated to compute the estimates of the $\mathrm{P}$ composition of the gain at various EBWs: $\mathrm{P}$ content $(\mathrm{g} / \mathrm{kg}$ of gain $)=\mathrm{b} \times 10^{\mathrm{a}} \times \mathrm{EBW}^{(\mathrm{b}-1)}$. The net $\mathrm{P}$ requirements of the gain in $\mathrm{BW}$ were obtained through the conversion of EBW into BW. The lambs fed at restricted levels of intake were not included in the prediction equation due to their growth pattern differing from those fed ad libitum.

\section{Statistical analyses}

Statistical analyses were performed using SAS 8.1 (SAS Inst. Inc., Cary, USA). Prior to the procedures of general linear model (GLM), the values of mean, standard deviation, standard error, minimum and maximum were calculated using PROC MEANS procedure for all dependent variables to validate the data sets, an outlier analysis was conducted using the calculated mean \pm 3 standard deviations (SD) of each dependent variable, and no observations were removed based on this analysis. Then the analysis of observations of intake, dietary $\mathrm{P}$ contents, body composition and growth rates was performed using GLM, and the comparison of the means was carried out by the Duncan test at $\mathrm{p}=0.05$. Linear regressions were conducted using PROC REG with the model $\mathrm{y}=\alpha+\beta \mathrm{x}+\varepsilon$, where $\mathrm{y}$ is the expected response, $\mathrm{x}$ is the independent variable, $\alpha$ is the $y$-intercept; $\beta$ is the slope of the regression line; $\varepsilon$ is the standard error of parameter estimate. The assumptions of the model for homoscedasticity, independency, and normality of the errors were examined by plotting residuals against the predicted values.

\section{RESULTS AND DISCUSSION}

\section{Nutrient intake, growth performance and initial body $P$ content}

The feeds composition and nutrient levels of the experimental diet are shown in Table 1. P intake or ADG was highly correlated with DMI $(r=0.99$ and 0.94, respectively) (Table 2). According to NRC (2007), the ad libitum intake, 70 or $40 \%$ of ad libitum intake lambs were expected to achieve gains of 300,200 or $0 \mathrm{~g} / \mathrm{d}$, respectively. In the present study, corresponding growth rates were 294.9, 189.1 and $37.9 \mathrm{~g} / \mathrm{d}$, respectively.

An equation between empty body $\mathrm{P}$ and EBW was established as: $\log _{10}$ (empty body $\left.\mathrm{P}, \mathrm{g}\right)=0.659( \pm 0.350)+$ $\left[1.103( \pm 0.283) \times \log _{10} \mathrm{EBW}, \mathrm{kg}\right]\left(\mathrm{r}^{2}=0.75\right.$; root mean square error $(\mathrm{RMSE})=0.022 ; \mathrm{n}=7 ; \mathrm{p}=0.0114)$. The slope was different from 1 in this equation $(\mathrm{p}<0.05)$. Initial EBW of each animal was computed from initial SBW $\left(\mathrm{r}^{2}=0.94\right.$; $\mathrm{RMSE}=0.351 ; \mathrm{n}=7 ; \mathrm{p}=0.0012): \mathrm{EBW}, \mathrm{kg}=2.488$ $( \pm 1.854)+[0.758( \pm 0.093) \times \mathrm{SBW}, \mathrm{kg}]$.

\section{Maintenance requirements}

The maintenance requirement of $\mathrm{P}$ for sheep was estimated as total endogenous loss (NRC, 2007), which is 
Table 2. Intake and P metabolism of Dorper $\times$ thin-tailed Han crossbred ram lambs ${ }^{\mathrm{d}}$

\begin{tabular}{|c|c|c|c|c|c|}
\hline \multirow{2}{*}{ Items } & \multicolumn{3}{|c|}{ Treatment } & \multirow{2}{*}{ SEM } & \multirow[b]{2}{*}{$\mathrm{p}$} \\
\hline & $\mathrm{AL}$ & $70 \%$ & $40 \%$ & & \\
\hline No. of lambs & 14 & 7 & 7 & - & - \\
\hline DMI $(\mathrm{kg} / \mathrm{d})$ & $1.21^{\mathrm{a}}$ & $0.90^{\mathrm{b}}$ & $0.51^{\mathrm{c}}$ & 0.024 & $<0.0001$ \\
\hline DMI $(\mathrm{kg} / \mathrm{kg}$ EBW·d $)$ & $0.05^{\mathrm{a}}$ & $0.04^{\mathrm{b}}$ & $0.03^{\mathrm{c}}$ & 0.001 & $<0.0001$ \\
\hline$P$ intake $(g / d)$ & $4.02^{\mathrm{a}}$ & $3.00^{\mathrm{b}}$ & $1.69^{\mathrm{c}}$ & 0.079 & $<0.0001$ \\
\hline$P$ retained $(\mathrm{g} / \mathrm{d})$ & $1.16^{\mathrm{a}}$ & $0.73^{\mathrm{a}}$ & $0.21^{\mathrm{b}}$ & 0.050 & $<0.0001$ \\
\hline$P$ retained $(\mathrm{g} / \mathrm{kg}$ EBW$\cdot \mathrm{d})$ & $0.04^{\mathrm{a}}$ & $0.03^{\mathrm{b}}$ & $0.01^{\mathrm{c}}$ & 0.002 & $<0.0001$ \\
\hline
\end{tabular}

$\overline{\mathrm{a}, \mathrm{b}, \mathrm{c}}$ In the same row, different superscript letters indicate significant differences $(\mathrm{p}<0.05)$.

${ }^{\mathrm{d}}$ DMI $=$ Dry matter intake, EBW $=$ Empty body weight, $\mathrm{ADG}=$ Average daily gain, $\mathrm{AL}=$ Ad libitum, $70 \%=\mathrm{Restricted}$ to $70 \%$ of ad libitum, 40\% $=$ Restricted to $40 \%$ of ad libitum, SEM = Standard error of the mean.

the sum of inevitable (or unavoidable) endogenous fecal $\mathrm{P}$ plus endogenous urinary $\mathrm{P}$ when an animal is fed near its true requirement (i.e., zero $\mathrm{P}$ balance). Urinary excretion of $\mathrm{P}$ is normally low in healthy animals, inevitable fecal $\mathrm{P}$ is therefore the main part of the total $\mathrm{P}$ maintenance requirement (Myers and Beede, 2009). AFRC (1991) ignored endogenous losses in urine and estimated total endogenous loss based on DMI of high-quality diets with the following equation: $\mathrm{P}(\mathrm{g} / \mathrm{d})=0.693 \times \mathrm{DMI}(\mathrm{kg} / \mathrm{d})-0.06$. However, salivary $\mathrm{P}$, which was influenced by many factors such as DMI, physical dietary characteristics, and dietary $\mathrm{P}$ content, was the main determinant of fecal endogenous $\mathrm{P}$ (Bravo et al., 2003). AFRC (1991) therefore applied a 1.6 factor to the equation above to compensate for salivary $\mathrm{P}$ loss.

Many factors influence the estimates of $\mathrm{P}$ requirements obtained from different studies, so a more strict method was needed in estimating the $\mathrm{P}$ requirement. As a slaughter trial is a direct measurement with improved accuracy, this technique is adopted commonly to estimate the protein and energy requirement for maintenance (Chizzotti et al., 2007; Fernandes et al., 2007; Galvani et al., 2008; 2009). Consequently, we conducted a slaughter trial to calculate the retained $\mathrm{P}$, and estimate the $\mathrm{P}$ requirement for maintenance.
As expected, the retained $\mathrm{P}$ was highly correlated with DMI $(r=0.97)$ (Table 2). Thus a linear relationship between retained $\mathrm{P}(\mathrm{g} / \mathrm{kg} \mathrm{EBW} \cdot \mathrm{d})$ and DMI $(\mathrm{kg} / \mathrm{kg} \mathrm{EBW} \cdot \mathrm{d})$ was found.

The equation accounting for the relationship between retained $\mathrm{P}$ and DMI was $\left(\mathrm{RMSE}=0.006, \mathrm{p}<0.0001, \mathrm{r}^{2}=\right.$ $0.826)$ : retained $\mathrm{P}(\mathrm{g} / \mathrm{kg}$ of $\mathrm{EBW} \cdot \mathrm{d})=1.607( \pm 0.145) \times \mathrm{DMI}$ $(\mathrm{kg} / \mathrm{kg}$ of EBW·d)-0.030( \pm 0.006$)$ (Figure 1). Theoretically, a lamb with a DMI of $0 \mathrm{~kg} / \mathrm{kg}$ EBW per day is expected to retain $-0.030 \mathrm{~g} \mathrm{P}$, which represented the $\mathrm{P}$ requirement for maintenance. Additionally, the linear relationship between EBW and BW was $\left(\mathrm{RMSE}=0.577, \mathrm{p}<0.0001, \mathrm{r}^{2}=0.984\right)$ : $\mathrm{EBW}, \mathrm{kg}=2.830( \pm 0.455)+0.691( \pm 0.015) \times \mathrm{BW}, \mathrm{kg}$, in which all the data in the experiment was used. So the $\mathrm{P}$ requirement for maintenance was $23.4 \mathrm{mg} / \mathrm{d}$ when expressed as per unit of BW. Some previous studies derived the net $\mathrm{P}$ maintenance requirement via balance trials. Portilho (2006) suggested a minimum $\mathrm{P}$ requirement for lambs reared under tropical conditions to be $42.3 \mathrm{mg} / \mathrm{kg}$ live weight. Additionally, Vitti et al. (2005) estimated the daily minimum endogenous faecal P loss as $8.63 \mathrm{mg} / \mathrm{kg}$ of BW in Suffolk sheep. ARC (1965) estimated the P requirement for maintenance as $42.5 \mathrm{mg} / \mathrm{kg} \mathrm{BW}$, which later was reduced to $14 \mathrm{mg} / \mathrm{kg} \mathrm{BW}$ (ARC, 1980) based on

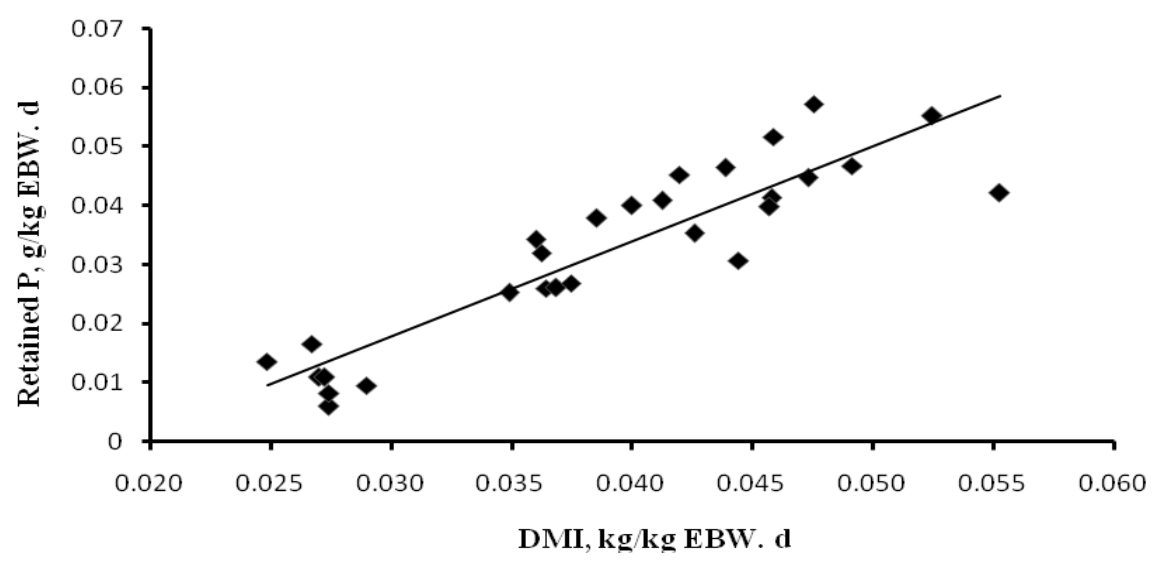

Figure 1. Relationship between retained $P$ and DMI of Dorper $\times$ thin-tailed Han crossbred ram lambs. Retained $P(g / k g$ EBW) $=$ $1.607( \pm 0.145) \times$ DMI $(\mathrm{kg} / \mathrm{kg}$ EBW $)-0.030( \pm 0.006)\left(\mathrm{RMSE}=0.006 ; \mathrm{p}<0.0001 ; \mathrm{r}^{2}=0.826 ; \mathrm{n}=28\right)$. 
Table 3. DMI and body $\mathrm{P}$ composition of Dorper $\times$ thin-tailed Han crossbred ram lambs ${ }^{\mathrm{d}}$

\begin{tabular}{|c|c|c|c|c|c|}
\hline \multirow{2}{*}{ Items } & \multicolumn{3}{|c|}{ Treatment } & \multirow{2}{*}{ SEM } & \multirow{2}{*}{$\mathrm{p}$} \\
\hline & Initial slaughter & intermediate slaughter & Final slaughter & & \\
\hline No of lambs & 7 & 7 & 7 & - & - \\
\hline DMI (kg/d) & - & $1.16^{\mathrm{b}}$ & $1.27^{\mathrm{a}}$ & 0.04 & 0.0131 \\
\hline $\mathrm{ADG}(\mathrm{g} / \mathrm{d})$ & - & 280.95 & 308.93 & 22.13 & NS \\
\hline BW (kg) & $21.16^{\mathrm{c}}$ & $30.91^{\mathrm{b}}$ & $38.01^{\mathrm{a}}$ & 0.95 & $<0.0001$ \\
\hline SBW (kg) & $19.93^{\mathrm{c}}$ & $28.54^{\mathrm{b}}$ & $35.61^{\mathrm{a}}$ & 0.87 & $<0.0001$ \\
\hline EBW (kg) & $17.40^{\mathrm{c}}$ & $24.07^{\mathrm{b}}$ & $29.10^{\mathrm{a}}$ & 0.61 & $<0.0001$ \\
\hline Body $\mathrm{P}$ contents $\mathrm{g}$ & $106.68^{\mathrm{c}}$ & $137.92^{\mathrm{b}}$ & $167.71^{\mathrm{a}}$ & 4.19 & $<0.0001$ \\
\hline
\end{tabular}

$\overline{\mathrm{a}, \mathrm{b}, \mathrm{c}}$ In the same row, different superscript letters indicate significant differences $(p<0.05)$.

${ }^{\mathrm{d}}$ DMI $=$ Dry matter intake, $\mathrm{BW}=$ Body weight, $\mathrm{SBW}=$ Shrunk body weight, $\mathrm{EBW}=$ Empty body weight, $\mathrm{ADG}=$ Average daily gain, $\mathrm{SEM}=$ Standard error of the mean.

total endogenous loss. NRC (1985) calculated total endogenous loss as $20 \mathrm{mg} / \mathrm{kg} \mathrm{BW}$ per day for sheep at maintenance, which was $15 \%$ less than what we found. However, Vitti et al. (2000) used a P metabolism model to compute $\mathrm{P}$ exchanges estimated the $\mathrm{P}$ maintenance in Saanen goats of $25 \mathrm{~kg} \mathrm{BW}$ to be $0.61 \mathrm{~g} / \mathrm{d}$, and this recommendation was also adopted by Suttle (2010), it is adaptable when comparing with the value we achieved as 0.50 to $0.81 \mathrm{~g} / \mathrm{d}$. A re-evaluation showed that the endogenous losses of $\mathrm{P}$ were influenced by feed ingested, diet quality, as well as the factors linked to competition for absorbed P by secretion mechanism (AFRC, 1991), and salivary $\mathrm{P}$ also played an important role in $\mathrm{P}$ metabolism (NRC, 2007). Furthermore, P loss may also happen when dandruff and wool shed from the body. So the estimates in current study would be more accurate by taking all the influences into account using slaughter trial.

\section{Growth requirements}

Body $\mathrm{P}$ contents linearly increased with the increasing EBW $(r=0.97)$ (Table 3$)$. The allometric equation describing the relationship between body $\mathrm{P}$ contents and EBW was $\left(\mathrm{RMSE}=0.022, \mathrm{p}<0.0001, \mathrm{r}^{2}=0.943\right)$ : Log (body $\mathrm{P}$ contents, $\mathrm{g})=0.938( \pm 0.068)+0.876( \pm 0.049) \times \log$ (EBW, kg) (Figure 2). Net $\mathrm{P}$ requirement for growth, $\mathrm{g} / \mathrm{kg}$ $\mathrm{EBW}=7.59 \times \mathrm{EBW}^{-0.124}$, was calculated accordingly.

Our finding indicated that the net $\mathrm{P}$ requirement for growth decreased from 5.3 to $5.0 \mathrm{~g} / \mathrm{kg}$ of EBW gains as lambs grew from 20 to $35 \mathrm{~kg}$ of SBW. Similar decrease was also reported in cattle (Cheizzotti et al., 2009) and goats (Gomes et al., 2011), which might have been associated with the decreasing growth rate of the bone with maturity (NRC, 2007).

The estimates of net $\mathrm{P}$ requirement for growth of sheep vary with nutritional systems. Previous estimate of $\mathrm{P}$ requirement for growth was $6 \mathrm{~g} / \mathrm{kg}$ empty body weight gain (EBG) (ARC, 1980; NRC, 1985), which was then adopted by AFRC (1998), but the NRC (2007) estimate ranged from 5.1 to $7.3 \mathrm{~g} / \mathrm{kg}$ live weight gain, and a value of $6.5 \mathrm{~g} / \mathrm{kg}$ live weight gain for goats was also recommended. It is accepted that goats generally had a higher bone ratio in the body than sheep (AFRC, 1997), and they had a higher P concentration in bone (NRC, 1980; Bellof and Pallauf, 2007), which may cause a greater $\mathrm{P}$ requirement for goats than for sheep. Furthermore, in a comparative slaughter trial, Araujo (2010) found that the net $\mathrm{P}$ requirement for growth decreased from

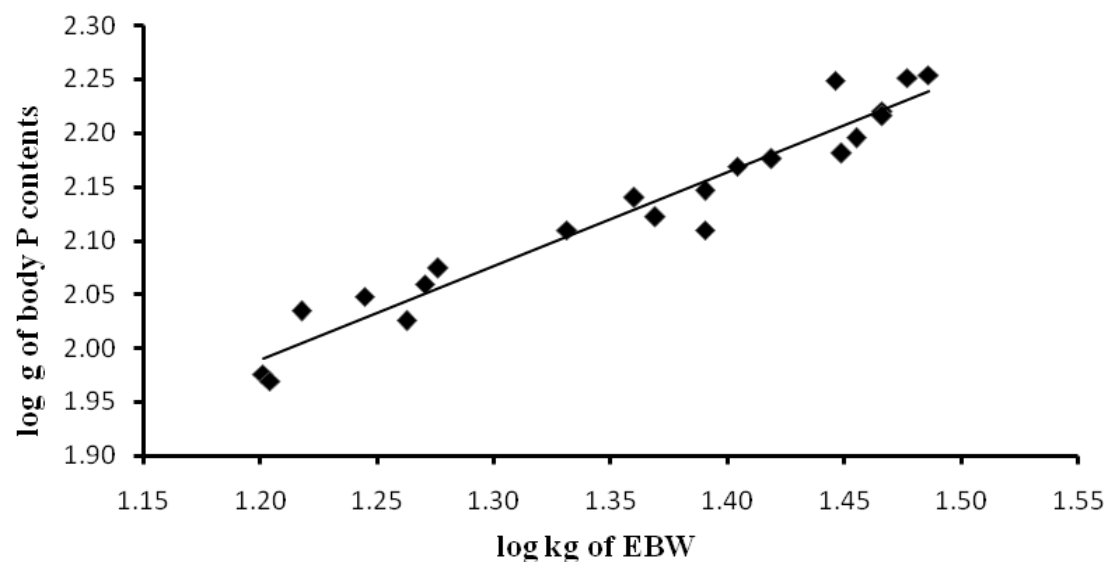

Figure 2. Relationship between body $\mathrm{P}$ contents and EBW of Dorper $\times$ thin-tailed Han crossbred ram lambs. Log (body P contents, $\mathrm{g}$ ) $=$ $0.938( \pm 0.068)+0.876( \pm 0.049) \times \log (\mathrm{EBW}, \mathrm{kg})\left(\mathrm{RMSE}=0.022 ; \mathrm{p}<0.0001 ; \mathrm{r}^{2}=0.943 ; \mathrm{n}=21\right)$. 
Table 4. Net $P$ requirements of Dorper $\times$ thin-tailed Han crossbred ram lambs ${ }^{\mathrm{a}}$

\begin{tabular}{|c|c|c|c|c|c|}
\hline \multirow{2}{*}{ Item } & & \multicolumn{4}{|c|}{$\mathrm{BW}(\mathrm{kg})$} \\
\hline & & 20 & 25 & 30 & 35 \\
\hline \multicolumn{2}{|l|}{$\overline{\text { EBW (kg) }}$} & 16.65 & 20.11 & 23.56 & 27.02 \\
\hline \multicolumn{2}{|c|}{ Requirement for maintenance $(\mathrm{g} / \mathrm{d})$} & 0.50 & 0.60 & 0.71 & 0.81 \\
\hline \multicolumn{6}{|c|}{ Requirement for growth } \\
\hline \multirow[t]{3}{*}{$\mathrm{ADG}(\mathrm{g} / \mathrm{d})$} & 100 & 0.53 & 0.52 & 0.51 & 0.50 \\
\hline & 200 & 1.07 & 1.05 & 1.03 & 1.01 \\
\hline & 300 & 1.61 & 1.57 & 1.54 & 1.51 \\
\hline \multicolumn{6}{|c|}{ Net requirement ${ }^{b}$} \\
\hline \multirow[t]{3}{*}{$\mathrm{ADG}(\mathrm{g} / \mathrm{d})$} & 100 & 1.04 & 1.13 & 1.22 & 1.31 \\
\hline & 200 & 1.57 & 1.65 & 1.73 & 1.82 \\
\hline & 300 & 2.11 & 2.17 & 2.25 & 2.32 \\
\hline
\end{tabular}

${ }^{\mathrm{a}} \mathrm{SBW}=$ Shrunk body weight, $\mathrm{BW}=$ Body weight, $\mathrm{ADG}=$ Average daily gain .

${ }^{\mathrm{b}}$ Net requirement is the sum of the requirement for maintenance and growth.

8.65 to $7.41 \mathrm{~g} / \mathrm{kg}$ EBG as Moxoto goats grew from 5 to 25 $\mathrm{kg}$ BW. Gomes (2011) estimated the requirement decreasing from 8.51 to $7.27 \mathrm{~g} / \mathrm{kg} \mathrm{BW}$ gain as Saanen goats grew from 5 to $20 \mathrm{~kg} \mathrm{BW}$. Bellof and Pallauf (2007) conducted a growth experiment with 108 German Merino lambs growing from 18 to $55 \mathrm{~kg}$ of $\mathrm{BW}$, and estimated the accretion of $\mathrm{P}$ as $7.5 \mathrm{~g} / \mathrm{kg}$ of EBG. Compared with the above reported values, the $\mathrm{P}$ requirement for growth of lambs estimated in our study was not constant but decreased from 5.3 to $5.0 \mathrm{~g} / \mathrm{kg}$ EBG as the animals matured, and our estimates are lower than those reported in the literature (Table 4).

\section{CONCLUSIONS}

The net $\mathrm{P}$ requirement for maintenance of Dorper $\times$ thintailed Han crossbred lambs was $30 \mathrm{mg} / \mathrm{kg}$ EBW or 23.4 $\mathrm{mg} / \mathrm{kg} \mathrm{BW}$, which is comparable with the recommendations of NRC (1985). The P requirement for growth was not constant but decreased from 5.3 to $5.0 \mathrm{~g} / \mathrm{kg}$ EBG as the lambs grew from 20 to $35 \mathrm{~kg}$ of SBW. These results suggested that the $\mathrm{P}$ requirement for growth of Dorper $\times$ thintailed Han crossbred lambs is lower than the value adopted by the American nutritional system.

\section{ACKNOWLEDGEMENTS}

The project was supported by the earmarked fund for Modern Agro-industry Technology Research System (Project No: CARS-39 and No: 200903006). The authors state that there are no actual or potential conflicts of interest.

\section{REFERENCES}

AFRC. 1991. Technical committee on responses to nutrients report

No. 6. A reappraisal of the calcium and $P$ requirements of sheep and cattle. Nutrition abstracts and reviews, 61:573-612.

AFRC. 1993. Energy and protein requirements of ruminants. An advisory manual prepared by the AFRC Technical Committee on Responses to Nutrients. CAB International, Wallingford, UK.

AFRC. 1997. Technical committee on responses to nutrients report No. 10. The nutrition of goats. Nutrition abstracts and reviews (series B) 61:573-612.

AFRC. 1998. The nutrition of goat. Report No. 10. Agricultural and Food Research Council. CAB International, Wallingford, UK.

AOAC. 1990. Official methods of analysis. 15th ed. Association of Official Analytical Chemists, Washington, DC.

Araujo, M. J., A. N. Medeiros, and I. A. M. A. Teixeira. 2010. Mineral requirements for growth of Moxoto goats grazing in the semi-arid region of Brazil. Small Rumin. Res. 93:1-9.

ARC. 1965. Nutrition requirements of farm livestock. 2. Ruminant. London, UK.

ARC. 1980. The nutrient requirements of ruminant livestock. Commonwealth Agricultural Bureaux, Slough, UK.

Bellof, G., and J. Pallauf. 2007. Deposition of major elements in the body of growing lambs of the German Merino Landsheep breed. Small Rumin. Res. 73:186-193.

Bravo, D., D. Sauvant, and C. Bogaert. 2003. III. Quantitative aspects of phosphorus excretion in ruminants. Reprod. Nutr. Dev. 43:285-300.

Cheng, P. 1984. Livestock breeds of China. FAO Animal Production and Health Paper No. 46. Food and Agriculture Organization of the United Nations, Rome.

Chizzotti, M. L., S. C. V. Filho, L. O. Tedeschi, F. H. Chizzotti, and G. E. Carstens. 2007. Energy and protein requirements for growth and maintenance of $F_{1}$ Nellore $\times$ Red Angus bulls, steers, and heifers. J. Anim. Sci. 85:1971-1981.

Chizzotti, M. L., S. C. V. Filho, and L. O. Tedeschi. 2009. Net requirement of calcium, magnesium, sodium, phosphorus, and potassium for growth of Nellore $\times$ Red Angus bulls, steers, and heifers. Livest. Sci. 124:242-247.

Cloete, S. W., M. A. Snyman, and M. J. Herselman. 2000. Productive performance of Dorper sheep. Small Rumin. Res. 36:119-135.

CSIRO. 2007. Nutrient requirements of domesticated ruminants. CSIRO Publishing, Collingwood, Australia.

Fernandes, M. H. M. R., K. T. Resende, and L. O. Tedeschi. 2007. Energy and protein requirements for maintenance and growth 
of Boer crossbred kids. J. Anim. Sci. 85:1014-1023.

Galvani, D. B., C. C. Pires, G. V. Kozloski, and T. P. Wommer. 2008. Energy requirements of Texel crossbred lambs. J. Anim. Sci. 86:3480-3490.

Galvani, D. B., C. C. Pires, and G. V. Kozloski. 2009. Protein requirements of Texel crossbred lambs. Small Rumin. Res. 81:55-62.

Gomes, R. A., D. Oliveira-Pascoa, and I. A. M. A. Teixeira. 2011. Macromineral requirements for growing Saanen goat kids. Small Rumin. Res. 99:160-165.

INRA. 1989. Ruminant nutrition: Recommended allowances and feed tables. John Libbey \& Co. Ltd, Paris, France.

McDowell, L. R. 1996. Feeding minerals to cattle on pasture. Anim. Feed Sci. Technol. 60:247-271.

Myers, Z. H. and D. K. Beede. 2009. Evaluating estimates of phosphorus maintenance requirement of lactating Holstein cows with different dry matter intakes. J. Dairy Sci. 92:708719.
NRC. 1985. Nutrient requirements of sheep, 6th rev. ed. National Academy Press, Washington, DC.

NRC. 2007. Nutrient requirements of small ruminants: Sheep, goats, cervids, and new world camelids. National Academy Press, Washington, DC

Portilho, F.P., D. M. Vitti, and A. L. Aldalla. 2006. Minimum phosphorus requirement for Santa Ines lambs reared under tropical conditions. Small Rumin. Res. 63:170-176.

Suttle, N. F. 2010. Mineral nutrition of livestock, 4th rev. ed. CABI Publishing, New York.

Vitti, D. M., E. Kebreab, and J. B. Lopes. 2000. A kinetic model of phosphorus metabolism in growing goats. J. Anim. Sci. 78:2706-2712.

Vitti, D. M., E. Kebreab, and J. B. Lopes. 2005. Effects of dietary supplementation on phosphorus metabolism in sheep. J. Anim. Vet. Adv. 4:349-355. 